\title{
Parque do Flamengo: projetar a cidade, desenhando patrimônio
}

Parque do Flamengo: designing the city, drawing heritage

\author{
MÁRCIA REGINA ROMEIRO CHUVA' \\ Universidade Federal do Estado do Rio de Janeiro / Rio de Janeiro, RJ, Brasil
}

RESUMO: Trata-se de uma narrativa sobre o processo de patrimonialização do Parque do Flamengo, no Rio de Janeiro, tombado em 1965 pelo Instituto do Patrimônio Histórico e Artístico Nacional - Iphan. $\bigcirc$ Parque foi projetado pelo arquiteto Affonso Eduardo Reidy e o paisagista Roberto Burle Marx, ligados à "escola carioca" de arquitetura moderna. $\bigcirc$ artigo estabelece conexões entre esse processo e a constituição do campo arquitetônico no Brasil, abordando as políticas de proteção de bens arquitetônicos e paisagísticos modernos promovidas pelo Iphan. Essas análises estão situadas no bojo do intenso processo de reformas urbanas implementadas na cidade do Rio de Janeiro, no governo de Carlos Lacerda, primeiro governador do estado da Guanabara, no conturbado contexto político nacional de golpe militar e instalação do regime autoritário no Brasil. $\bigcirc$ artigo explora ainda os valores de patrimônio acionados na preservação do Parque do Flamengo no contexto em que o Rio de Janeiro torna-se palco de grandes eventos esportivos e recebe o título da Unesco de Patrimônio Mundial na categoria de Paisagem Cultural, ao passo que a agenda contemporânea do campo do patrimônio coloca na ordem do dia o debate sobre a sua função social. Espera-se contribuir com reflexões sobre patrimônio na chave do direito à cidade, problematizando o tradicional confronto entre preservação cultural e especulação imobiliária. O material empírico privilegiado foi o processo de tombamento do Parque do Flamengo e as atas do Conselho Consultivo do Iphan relacionadas ao assunto.

PALAVRAS-CHAVE: Parque do Flamengo. Patrimônio paisagístico. Reformas urbanas. Rio de Janeiro. Patrimônio mundial. Iphan.

ABSTRACT: The article proposes a narrative about the process of heritagization of Parque do Flamengo (Flamengo Park), in Rio de Janeiro, in 1965, by Brazilian National Institute for Heritage (Iphan). The Park was designed by the architect Affonso Eduardo Reidy and the landscape architect Roberto Burle Marx, both linked to the group of Modernist Carioca School. The article

\begin{abstract}
1. Professora do Departamento de História e do Programa de Pós- Graduação em História da Universidade Federal do Estado do Rio de Janeiro (PPGH-UNIRIO) e do Mestrado Profissional em Patrimônio Cultural do Instituto do Patrimônio Histórico e Artístico Nacional - PEP-IPHAN. Doutora em História pela Universidade Federal Fluminense (1998), com Pós-Doutorado na Universidade de Coimbra (2015). Email: $<$ marciachuva@gmail.com>.
\end{abstract}


2. Utilizaremos, ao longo do texto, indistintamente, as denominações Parque do Flamengo, Aterro, Aterro do Flamengo, ou Parque do Aterro do Flamengo.

3. Em 2015, foi montada a exposição Jardins da Memória, com a curadoria da arquiteta Margareth Pereira, comemorando os 50 anos do Aterro do Flamengo. Ver IAB (2015). makes connections between this process and the constitution of the field of architecture in Brazil, especially the policies aimed at the protection of modern architectural and landscape assets promoted by Iphan. The context is the midst of intense urban reforms in the city of Rio de Janeiro under the government of Carlos Lacerda, first governor of the state of Guanabara, in the troubled national political context of a military coup and the establishment of the authoritarian regime in Brazil. It also explores the ways for preservation of Parque do Flamengo when Rio de Janeiro hosted major sporting events and received the Unesco title of World Heritage Cultural Landscape, while the contemporary agenda of the field is the debate on the social function of heritage. It is hoped to contribute with reflections on heritage in the key of the rights to the city, problematizing the traditional confrontation between preservation and the real estate speculation. The privileged empirical material was the process of registration of Parque do Flamengo as Brazilian Cultural Heritage and the Reports of the Consultative Council of Cultural Heritage Meetings that Parque do Flamengo was under debate.

KEYWORDS: Parque do Flamengo. Landscape heritage. Urban reforms. Rio de Janeiro. World heritage. Brazilian National Institute for Heritage - Iphan.

\section{INTRODUÇÃO}

Chamado pelos cariocas simplesmente de Aterro, em 2015 o Parque do Flamengo completou 50 anos como uma rara unanimidade em termos de projeto urbanístico admirado e usufruído na cidade do Rio de Janeiro. ${ }^{2}$ Localizado entre o Aeroporto Santos Dumont e a Praia de Botafogo, em terreno artificial ganho ao mar por meio da deposição de terras vindas da destruição de morros e trechos da cidade, é considerado o maior parque urbano do mundo e a maior área de lazer ao ar livre da cidade. Informações transbordam na internet e numa busca ligeira aparecem fotografias, filmes, sites, indicações de livros e exposição. ${ }^{3}$ É possível ter acesso a imagens sobre o Parque do Flamengo desde o desmonte final do Morro de Santo Antônio, de onde foi retirada a maior parte do material para o aterramento do mar e a construção dos aterros até as obras e a sua inauguração. Também são abundantes as vistas aéreas, explorando a beleza da paisagem. Tal como descrito no seu sítio eletrônico oficial, trata-se de uma área de lazer das mais frequentadas na cidade, um "parque vivo" que conta com "um imenso jardim onde você pode 
contemplar variada flora, fauna e a bela paisagem da Baía de Guanabara", com farta lista de equipamentos culturais, de recreação e esportes. ${ }^{4}$

O Parque do Flamengo foi inaugurado em 1965, no contexto das comemorações do Quarto Centenário da fundação do Rio de Janeiro, como parte de um projeto de modernização que reinventava sua magnitude, ainda combalida por ter deixado de ser sede da República em 1960, com a transferência da capital federal para a cidade de Braślia. Sua construção foi levada a cabo por Carlos Lacerda, primeiro governador da Guanabara, responsável também pelo pedido de tombamento do Parque encaminhado à Diretoria de Patrimônio Histórico e Artístico Nacional (DPHAN) $)^{5}$ em 1964, antes mesmo da sua inauguração e poucos meses após o golpe de 31 de março, que instalara a ditadura militar no Brasil.

A temática central do artigo toma como fio condutor o processo de patrimonialização do Parque do Flamengo pelo Iphan, no contexto do intenso processo de reformas urbanas sofrido pela cidade do Rio de Janeiro em meados da década de 1960, explorando os argumentos que tornam o seu tombamento uma questão de política urbana e que privilegiam a paisagem ali criada. No âmbito das políticas de patrimônio voltadas para jardins e bens paisagísticos, a preservação do Parque do Flamengo, verificada ao longo do tempo, tem dado ênfase aos seus atributos espaciais e arquitetônicos e às suas áreas livres, consideradas non aedificandi, em lugar da perspectiva da preservação de jardins e toda a problemática a ela subjacente. Os grandes eventos esportivos ocorridos na cidade nos anos 2000 trouxeram novas questões à gestão desse bem tombado, abordadas nos debates que tiveram lugar no Conselho Consultivo do Patrimônio Cultural, do Iphan. Por meio do recorte temático aqui proposto, temos a intenção de trazer elementos que contribuam com a reflexão sobre a função social do patrimônio na chave de leitura do direito à cidade.

O artigo está estruturado em três partes. A primeira examina a construção do Parque do Aterro do Flamengo como um projeto moderno que integra a política de modernização implementada por Carlos Lacerda, ressaltando as similaridades com a cidade moderna que se concretiza em Brasília. São destacadas as tensões, ambiguidades e contradições do projeto de cidade que propicia a fruição (de jardins ou paisagens) e, ao mesmo tempo, privilegia os deslocamentos de carro.

A segunda parte analisa o processo que levou à patrimonialização do Parque do Flamengo, verificando os valores atribuídos à paisagem e à sua dimensão social, no momento do tombamento, que ocorre em 1965. Veremos que a modernização na qual se inscrevia o Parque seria também a principal motivação para o seu tombamento, tendo em vista a intenção de protegê-lo da especulação imobiliária que se expandia com ela. Os valores destacados apontam para o
4. Os equipamentos esportivos são: campos de pelada; pistas de skate, patinação, bicicross e aeromodelismo; tanque de nautimodelismo; ciclovia; quadras de basquete, vôlei, power soccer, futsal, tênis, gateball; playground, cidade das crianças, parkour; postos de salvamento e a praia. E os equipamentos de caráter cultural são: o Museu de Arte Moderna e o Monumento Nacional aos Mortos da Segunda Guerra Mundial (construções anteriores que foram integradas ao projeto do Parque), a Marina da Glória, o Teatro de Marionetes, o Teatro de Arena, um coreto, pavilhões recreativos e o Monumento a Estácio de Sá, além dos quiosques de alimentação e restaurantes. Ver Parque do Flamengo (2017).

5. O Iphan teve outras denominações, tais como SPHAN - Serviço do Patrimônio Histórico e Artístico Nacional, nos primeiros anos de funcionamento, e DPHAN - Diretoria de Patrimônio Histórico e Artístico Nacional. Optamos por utilizar a denominação correspondente a cada período, respeitando a forma como aparece na documentação. Ver Analucia Thompson (2015). 
6. Sobre o conceito de modernização autoritária, ver Francisco Carlos Teixeira da Silva (2000).

7. Cf. Lauro Cavalcanti (2001, p. 94).

8. Novacap (Companhia Urbanizadora da Nova Capital do Brasil) era a marca da companhia responsável pela construção de Brasília. O Rio de Janeiro foi apelidado de Belacap quando perdeu o status de capital da República, em contraponto a Novacap, como também era chamada Brasília.

9. Sobre a escola modernista carioca, ver Paulo Cesar Garcez Marins (2016).

10. Ver Márcia Regina Romeiro Chuva (2003 e 2009).

11. Para o assunto, ver Lauro Cavalcanti (1995) e Maurício Lissovsky e Paulo Sérgio Moraes de Sá (1996). regramento da ocupação do espaço público, que caracterizou a gestão higienizadora do governo Lacerda em sintonia com o controle social e a modernização autoritária imposta pela ditadura militar. ${ }^{6}$

A terceira parte examina as tensões em torno da preservação do Parque do Flamengo na agenda contemporânea, especialmente a partir dos anos 2000, quando a cidade sediou grandes eventos esportivos, como os Jogos Pan-americanos em 2007 e os Jogos Olímpicos em 2016. A persistência dos valores da paisagem, em detrimento da perspectiva dos jardins, é examinada ao lado do valor social, posto em concorrência com a especulação imobiliária, aqui percebida como um modo ordinário de operar o mercado do solo urbano no Rio de Janeiro, extremamente disputado nesse contexto.

\section{PROJETAR A CIDADE: ENTRE O MODERNO E A MODERNIZAÇÃO}

A utopia da cidade moderna concretizou-se no Brasil com a inauguração de Brasília em 1960. A concepção de cidade-jardim, que influenciou ao menos as áreas residenciais nas superquadras do Plano Piloto, priorizava a escala humana e confrontava-se com a modernização do automóvel, que teve lugar privilegiado no desenho do sistema viário que estruturou a capital.

O Parque do Flamengo na cidade do Rio de Janeiro foi projetado em padrões similares, com seus 1.251.244,20 $\mathrm{m}^{2}$ de área total - dos quais menos de um terço é relativo às pistas de alta velocidade, rótulas e retornos. $\bigcirc$ Aterro de Carlos Lacerda, na leitura de Lauro Cavalcanti, ${ }^{7}$ converteu-se no "espelho carioca do plano para a nova capital", e o modernismo arquitetônico da Novacap (Braśília) teria um representante à altura na Belacap (Rio). ${ }^{8}$

Os arquitetos que projetaram Brasília e o Parque do Flamengo pertenciam a uma rede formada ainda nos anos 1930, que se tornou hegemônica nos campos da arquitetura e do patrimônio no Brasil, e posteriormente foi chamada de "escola carioca" de arquitetura moderna. ${ }^{9}$ Figura articuladora desse grupo, Lucio Costa ocupava um tríplice lugar de mentor: não só da nova arquitetura, como também dos caminhos para a autonomia da formação do arquiteto e ainda como mentor da história e da patrimonialização da arquitetura brasileira. ${ }^{10}$ Essa rede de arquitetos estabeleceu laços de amizade, provendo-se de postos de trabalho e consagrou-se como fundadora da arquitetura moderna brasileira.

Fazia parte desse grupo a equipe que projetou com Lucio Costa, a partir do traço original de Le Corbusier, a sede do Ministério da Educação e Saúde, 
inaugurada em 1945, e que se tornaria marco da arquitetura moderna brasileira. ${ }^{11}$ Essa equipe, formada pelos arquitetos Jorge Moreira, Ernani Vasconcelos, Carlos Leão, Oscar Niemeyer, Affonso Eduardo Reidy e Roberto Burle Marx, ocupou espaços de projeção da arquitetura moderna brasileira. Logo, no contexto da criação, execução e patrimonialização do projeto do Parque do Flamengo, nos anos 1960, esses arquitetos já haviam sido consagrados, com trajetórias de sucesso e prêmios internacionais conquistados. ${ }^{12}$

Pertencente a esse grupo, Affonso Eduardo Reidy ${ }^{13}$ foi o autor do projeto arquitetônico e urbanístico do Parque do Flamengo, que pode ser visto na figura 1, a ser construído ao lado do Museu de Arte Moderna (MAM), projeto também de sua autoria e situado na zona contígua, do primeiro aterro da Avenida Beira-Mar. ${ }^{14}$

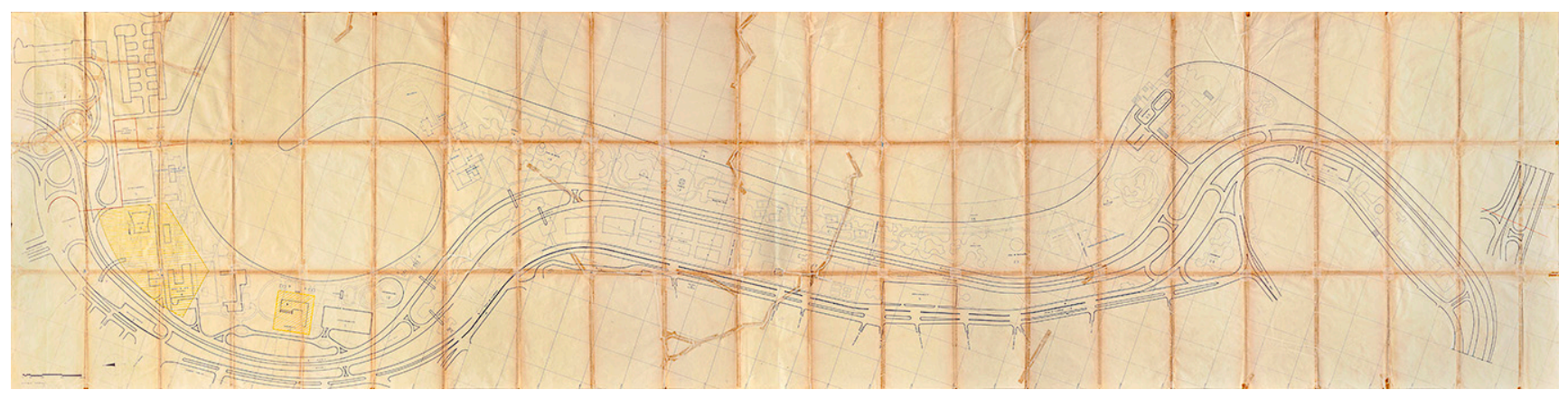

Figura 1 - Planta do Projeto do Aterro do Flamengo, que integra o volume II do Processo de Tombamento n. 0748-T-64. Arquivo Central do Iphan, Rio de Janeiro.

Ele foi também responsável pela maioria dos projetos arquitetônicos desenvolvidos para as atividades recreativas programadas por Ethel Bauzer Medeiros. ${ }^{15} \mathrm{O}$ projeto paisagístico ficou a cargo do Escritório Roberto Burle Marx e Arquitetos Associados. Os jardins do Aterro são classificados como "jardins modernos", por fazerem parte de uma tipologia de jardins que surgem de modo intrinsecamente associado ao movimento da Arquitetura Moderna. ${ }^{16}$ O papel de Roberto Burle Marx na invenção e disseminação do jardim moderno no Brasil e no mundo é recorrentemente destacado pela historiografia sobre o assunto, ${ }^{17}$ sendo impossível separar a história do jardim brasileiro da arquitetura moderna e de sua obra.

A escala humana teve prerrogativas no projeto detalhadamente concebido por Affonso Reidy, revelando no desenho as prioridades da cidade que projetava. Nela, a travessia dos pedestres não deveria ser penosa e, por isso, o arquiteto projetou o rebaixamento do solo para a construção das pistas, e passarelas de pedestres com uma curvatura bastante suave a ser vencida para

12. Ver Lauro Cavalcanti (2001).

13. Affonso Eduardo Reidy era arquiteto do Departamento de Urbanismo da Prefeitura do Rio de Janeiro. Nascido em Paris e radicado no Rio de Janeiro, é um dos pioneiros da arquitetura moderna, premiado na Bienal de Arquitetura de 1953 pelo projeto do Conjunto Habitacional do Pedregulho, no Rio de Janeiro. Morreu em 10 de agosto de 1964, antes da inauguração do Parque e da conclusão do seu tombamento. Ver Edson Mahfuz (2003). 
14. O projeto de iluminação do Aterro foi assinado pelo designer estadunidense Richard Kelly, que criou os famosos postes até hoje instalados. Os estudos hidrográficos para construção da praia artificial do Flamengo foram feitos pelo Laboratório Nacional de Engenharia Civil de Lisboa e a obra civil foi executada pela Superintendência de Urbanização e Saneamento (Sursan), sob a supervisão da engenheira Berta Leitchic. Ver Arquivo Central do Iphan (s.d.).

15. Ethel Bauzer Medeiros é pedagoga, especialista no campo de estudos sobre recreação e lazer. Tornou-se mestra em Educação na Northwestern University, Illinois, em 1949. Envolveu-se com ações de planejamento e capacitação de recreadores no Serviço Social da Indústria (Sesi) e no Serviço Social do Comércio (Sesc), ligados à Federação das Indústrias do Rio de Janeiro. Foi a primeira diretora da International Recreation Association em 1956 e primeira presidente da Associação Brasileira de Recreação (ABDR). Para mais informações, ver João Franco Lima (2009).

16. Cf. Cristiane Magalhães (2015, p. 353). O arquiteto russo Gregori Warchavchik introduziu no Brasil os jardins acoplados à arquitetura ao projetar as casas modernistas em São Paulo, em 1927, com jardins criados por Mirna Klabin.

17. Ana Rosa de Oliveira (2001), Alda de Azevedo Ferreira e Fernando Ono (2016), Cristiane Magalhães (2015), dentre outros. Ver também Burle Marx tratando da função do jardim (Roberto Burle Marx, 2004). atravessar as pistas e alcançar o parque. $\bigcirc$ modernismo e a modernização estavam ali presentes: no parque moderno projetado para a fruição e vivência do pedestre e nas grandes vias de carros, replicando no Rio as ambivalências do Plano Piloto de Brasília.

Podemos compreender também o Parque do Flamengo dentro do conjunto das grandes obras de modernização realizadas em função das comemorações do IV Centenário da fundação da cidade, em 1965. Maria Carlota de Macedo Soares (conhecida por Lota de Macedo Soares) imaginou essa grande área de lazer junto à zona aterrada à beira-mar para a construção de autopistas que interligariam rapidamente o Centro a Copacabana e convenceu o governador Carlos Lacerda a executá-la, criando um Grupo de Trabalho do Parque do Flamengo, presidido pela mesma. ${ }^{18}$

Personagem controvertido da vida política brasileira, segundo Marly Motta, "Lacerda ocupa um lugar especial no imaginário político nacional e carioca, já que encarnava, ao mesmo tempo, o tribuno incendiário, 'demolidor de presidentes', e o administrador competente, o 'construtor da Guanabara'". ${ }^{19}$ Como "construtor da Guanabara", foram marcantes as comemorações do IV Centenário, que, somadas à recuperação da cidade após a perda do status de capital federal, justificariam em boa medida as reformas urbanas que executou, desde a abertura de dois túneis ainda hoje de importância nerval para a conexão de áreas da cidade, o Rebouças e o Santa Bárbara, à construção do Parque do Flamengo, além da conclusão das obras da adutora do Guandu, dando solução a históricos problemas de abastecimento de água da cidade.

Maurício de Abreu, ${ }^{20}$ em seu clássico livro sobre a evolução urbana do Rio de Janeiro, apontava as grandes transformações que atingiam a cidade a partir dos anos 1950. Segundo ele, o governo Lacerda dedicou-se a adequar - espaço urbano às necessidades do automóvel e das classes que dele dispunham, por meio de uma série de obras para construção de vias expressas, de modo associado ao processo drástico de desmonte de morros e remoção de favelas do centro e dos locais mais valorizados da zona sul. Exemplo disso foi a remoção da favela do Morro do Pasmado, entre 1963 e 1964, localizado, justamente, no ponto em que se encerrariam as autopistas planejadas do Aterro do Flamengo. Essas obras provocaram a desestruturação de bairros como Lapa, Catumbi e Mangue - que serviam de residência para populações mais pobres. O Aterro do Flamengo resultou dessa grande intervenção na cidade, tendo em vista a demolição de casario antigo do Morro de Santo Antônio e o despejo da população, bem como o desmonte para a deposição das terras do morro nas margens da Baía de Guanabara. 
Todo esse reordenamento urbano forjava áreas livres em zonas valorizadas para a construção de habitações de luxo ou a manutenção de morros livres para a sua venda e incrementava um mercado imobiliário associado à especulação do solo urbano. Essas grandes reformas na cidade consolidariam uma distribuição social da população, que vinha sendo operada de modo mais intenso desde os anos 1950 e da qual as autopistas do Aterro faziam parte. As transformações urbanas se intensificariam nos anos subsequentes, facilitadas pela associação entre obras públicas do Estado e o capital privado de grandes empreiteiras, promovida pela ditadura militar. ${ }^{21}$

Foi nesse contexto que, em outubro de 1964, Carlos Lacerda encaminhou o pedido de tombamento do Parque do Flamengo à Diretoria do Patrimônio Histórico e Artístico Nacional - DPHAN, o que provocou a abertura do Processo n 748-T-64, concluído em abril de 1965, com sua aprovação pelo Conselho Consultivo da DPHAN para inscrição no Livro de Tombo Arqueológico, Etnográfico e Paisagístico e classificado como "jardim histórico" na Lista de Bens Tombados. ${ }^{22}$

Embora nascido patrimônio, o Parque do Flamengo, obviamente, não dispõe de valores a ele intrínsecos. Como todo bem patrimonializado, resultou de processos históricos de atribuição de valor, sendo ele, portanto, fruto de lutas de classificação em torno da fala hegemônica e do discurso autorizado do patrimônio. ${ }^{23}$

Vamos analisar o seu tombamento, explorando as tensões e argumentos presentes no processo de construção do valor de patrimônio do Parque do Flamengo. A patrimonialização serviria, nesse caso, como medida para enfrentar as pressões do mercado imobiliário que se organizava na cidade apoiado na prática da especulação imobiliária, tradicionalmente vista como inimiga mais perene do patrimônio, e ainda hoje em cena.

\section{DESENHANDO PATRIMÔNIO, ENTRE O ATERRO E O MAR}

Ao longo de três décadas de políticas de proteção ao patrimônio histórico e artístico brasileiro, implantadas a partir da criação do SPHAN, em 1937, com a direção e controle amiúde de Rodrigo Mello Franco de Andrade e a liderança técnica e intelectual de Lucio Costa, o barroco e o colonial tornaram-se os representantes mais dignos das origens da produção artística brasileira. Em meados dos anos 1960, eram reconhecidos como patrimônio histórico e artístico nacional. ${ }^{24}$ Tais origens tinham raízes europeias e, por isso mesmo, tornavam o Brasil um país moderno, integrado ao processo civilizador ocidental. Por meio dessa estratégia
18. Segundo Rodrigo de Faria, a criação desse grupo de trabalho não foi aceita de forma unânime no Departamento de Urbanismo da prefeitura. Em artigo publicado em 1963, José de Oliveira Reis desautorizava a fala de Maria Carlota de Macedo Soares, que, segundo ele, "expende opinião as mais disparatadas, sobre o que ignora”. Cf. José de Oliveira Reis apud Rodrigo de Faria (2017, p.110).

19. Cf. Marly Motta (2005, p. 75). Lacerda teve papel decisivo nos acontecimentos que levaram ao suicídio de Getúlio Vargas e também na articulação do movimento que precedeu a deposição do presidente João Goulart, para instalação da Ditadura Civil-Militar, em 1964. Ver também Marly Motta (2000 e 2004).

20. Ver Maurício de Abreu (1988, p. 118-135)

21. Para o assunto, ver Pedro Henrique Pedreira Campos (2014).

22. Cf. Lista dos Bens Tombados do Iphan. Iphan (2017).

23. Ver Laurajane Smith (2006).

24. Ver Lucio Costa (1937 e 1941) e também José Pessôa (1999). 
25. Cf. Processo n. 748-T-64

- Parque do Flamengo, composto de três volumes. O terceiro não estava disponível no momento da pesquisa no Arquivo Central do Iphan. O Parque do Flamengo, oficialmente denominado Parque Brigadeiro Eduardo Gomes, tem tombamento municipal (Lei $\mathrm{n}$. 2.287, de 4/1/1995).

26. Cf. Processo n. 748-T-64 - Parque do Flamengo. discursiva, esses agentes institucionais também protegeram a arquitetura moderna por eles ou seus pares projetada, reconhecendo a sua própria produção artística como herdeira do que chamaram a boa arquitetura e a boa tradição construtiva genuinamente brasileira, capaz de absorver sua alma e reinventála com as formas e materiais contemporâneos. O Parque do Flamengo, projetado no bojo desse pensamento, deve ser compreendido na mesma chave de uma estética moderna e civilizadora.

Tombado pela DPHAN antes mesmo de sua inauguração, ele foi patrimonializado ainda em projeto. Embora surpreendente, prática parecida com essa já ocorria desde os anos 1940, com o tombamento de bens arquitetônicos projetados por esse grupo pertencente à primeira geração de arquitetos da escola carioca. Tal prática foi inaugurada com o tombamento, em 1947, da lgreja de São Francisco de Assis e suas obras de arte, projeto de Oscar Niemeyer em Belo Horizonte, e até 1967 seis bens da arquitetura moderna haviam sido tombados. Surpreende também o gesto, aparentemente contraditório, de atribuição de valor de patrimônio a uma obra resultante da demolição de casario antigo do Morro de Santo Antônio, como vimos.

A seguir, serão analisados os trâmites do processo de tombamento do Parque do Flamengo, as tensões e os argumentos discursivos que foram acionados para justificar tal atitude.

A primeira peça que compõe o processo é o ofício, bastante sucinto, do governador Carlos Lacerda, datado de 27 de outubro de 1964: "Solicito a gentileza das providências de Vossa Senhoria no sentido de ser tombado por esse Serviço o Parque do Flamengo". ${ }^{25}$ A esse pedido segue o ofício de Rodrigo Mello Franco de Andrade, diretor da DPHAN, para a "Presidente do Grupo de Trabalho do Parque do Flamengo", Maria Carlota de Macedo Soares, solicitando "ser fornecido a esta diretoria o projeto geral do aludido Parque, com os pormenores elucidativos que the parecerem de interesse para apreciação do assunto" (10/1 1/1964). O ofício de Lota Macedo Soares, em resposta à solicitação do diretor da DPHAN, data de 3/12/1964, iniciando-se assim: "A urbanização do Aterro foi concebida pelo grupo de trabalho com o seguinte critério: a defesa e o enriquecimento da paisagem, e prestação de um serviço público para o povo carioca de caráter educacional e recreativo". ${ }^{26}$ Ela informa a dimensão da área reservada ao parque em contraponto com a área ocupada pelas pistas, rótulas e retornos e lista as obras já realizadas e ainda por fazer para a sua conclusão, tal como ilustra a figura 2.

Lota de Macedo Soares afirma ainda que:

Foi sempre a intenção do Grupo de Trabalho, desde o começo da planificação, de promover a Fundação do Parque do Flamengo, e de pedir ao digno Patrimônio Histórico e Artístico o tombamento, já que graças ao apoio incondicional do Governador Carlos Lacerda 
pudemos chegar a quasi conclusão das obras, sem que essas tenham sofrido uma quebra de unidade do projeto, ou a disvirtuação do conceito pelo qual elas foram criadas. Sobretudo, acreditamos que o nível tanto estético quanto social da obra venha a ser aceito pelos altos padrões que sempre nortearam o serviço do Patrimônio. [...] Pelo seu tombamento o Parque do Flamengo ficará protegido da ganância que suscita uma área de inestimável valor financeiro, e da extrema leviandade dos poderes públicos quando se tratar da complementação ou permanência dos planos. Uma obra que tem como finalidade a proteção à paisagem, e um serviço social para o grande público obedece a critérios ainda muito pouco compreendidos pelas administrações e pelos particulares. ${ }^{27}$

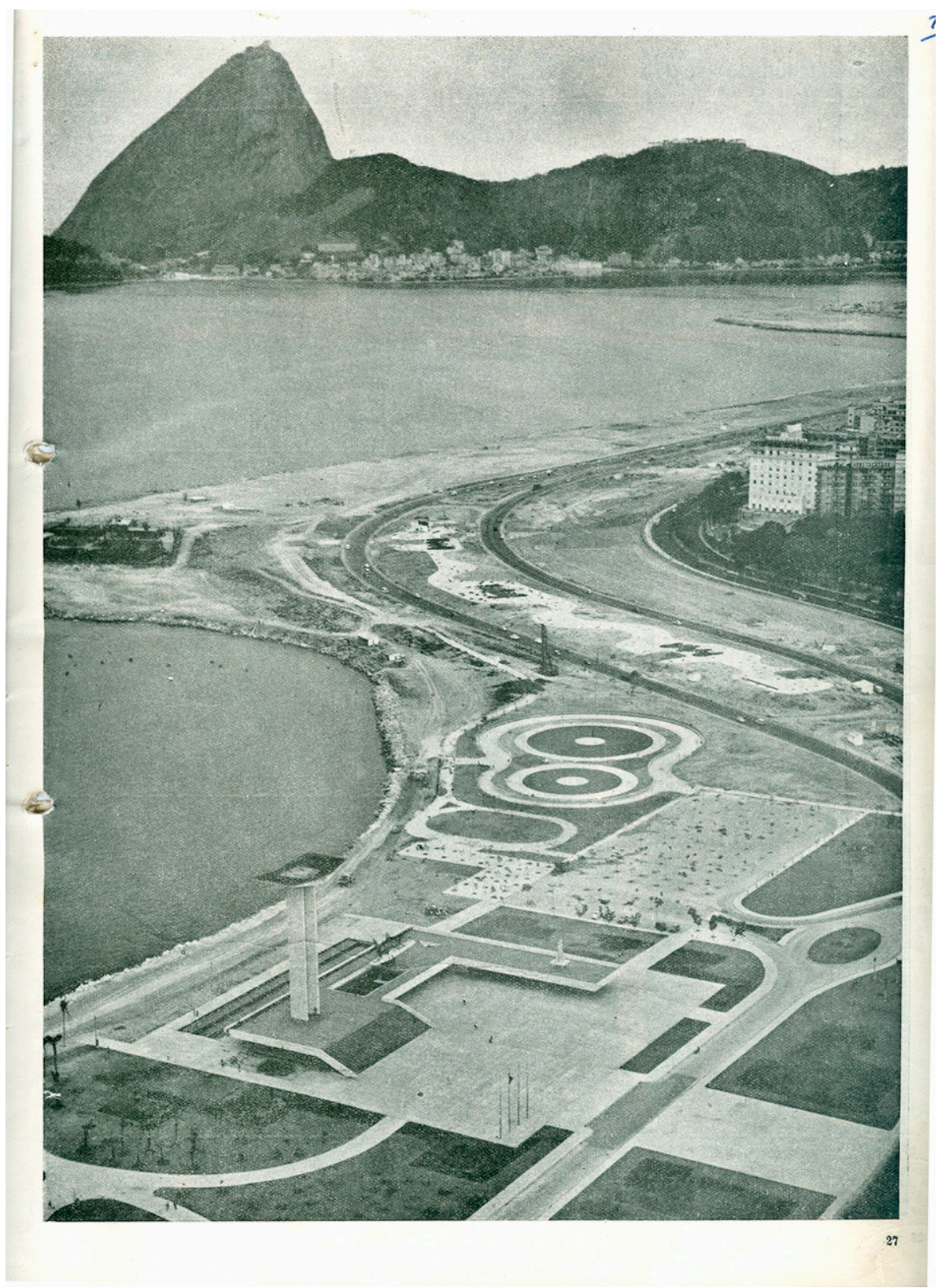

27. Cf. Processo n. 748-T-64

- Parque do Flamengo. Gri fos nossos.
Figura 2 - Autor não informado. Vista aérea do Parque do Flamengo em construção, que integra o volume I do Processo de Tombamento n. 0748-T64. Arquivo Central do Iphan, Rio de Janeiro. 
28. Ver Maurício de Abreu (1988).

29. Ver Pedro Henrique Pedreira Campos (2014).

30. Ver Rodrigo de Faria (2017).

31. Ver Rodrigo de Faria (2017).

32. Ver Rodrigo de Faria (2017).

33. Cf. Rodrigo de Faria (2017, p. 12).

34. Cf. Processo n. 748-T-64 - Parque do Flamengo. Grifo nosso.
Lota de Macedo Soares destaca valores estéticos, paisagísticos e sociais para justificar o pedido de tombamento, e reconhece o instrumento do tombamento como meio eficaz para enfrentar a especulação imobiliária que se configura na cidade. A percepção e o temor de Lota de Macedo Soares são bastante realistas, pois, como vimos anteriormente, ${ }^{28}$ tal especulação, nos anos 1960, confundia-se com as políticas urbanas associadas ao capital privado no Rio de Janeiro, e tornava-se parte do próprio modo de funcionamento e do controle do uso e ocupação do solo. ${ }^{29}$

Segundo Rodrigo de Faria, ${ }^{30}$ o projeto de criação de um parque associado às autopistas que estavam sendo abertas não era uma unanimidade dentro do Departamento de Urbanismo da Prefeitura. Talvez por isso, Lota de Macedo Soares preocupava-se com a urgência de sua proteção, a fim de evitar a transformação da área por administrações futuras. José de Oliveira Reis, engenheiro do referido Departamento, criticou severamente o projeto, por reduzir o número de vias que haviam sido planejadas com base em estudos prévios relativos ao crescimento da cidade. ${ }^{31}$ Esse debate mostrou tensões entre o Grupo de Trabalho do Parque do Flamengo e o Departamento de Urbanismo, que defendia o projeto que priorizava o automóvel no planejamento da cidade. Faria ${ }^{32}$ percebe aí indícios de um confronto de posições entre engenheiros e arquitetos dentro do Departamento de Urbanismo, no qual atuavam lado a lado José de Oliveira Reis e Affonso Reidy. Para o autor, havia "discordâncias instituídas pela compreensão de cidade associada aos seus lugares profissionais, à engenharia (para José de Oliveira Reis) e à arquitetura moderna (para Affonso Reidy)". ${ }^{33}$

Seguindo o trâmite burocrático do processo, Judith Martins, então chefe da seção de História da DPHAN, solicita parecer ao chefe da seção de Artes, o arquiteto Paulo Thedim Barreto, que assim se pronuncia: "Considerando o significado social-paisagístico do Parque do Flamengo e o valor dos seus elementos arquitetônicos, opinamos a favor do seu tombamento" (14/1 1/64) (grifo nosso). A pedido de Rodrigo Mello Franco de Andrade, Lucio Costa, como chefe da seção de Estudos de Tombamento, também apresenta o seu "De acordo" em 15/11/64. A seguir, no Processo, encontra-se o parecer do diretor-geral, Rodrigo Mello Franco de Andrade, de 8/1/1965, do qual destacamos:

...poder-se-ia objetar que seria descabido tombá-los enquanto a respectiva construção não estivesse totalmente terminada [...]. Não obstante, cumpre considerar que o objetivo da medida pleiteada pelo senhor governador do estado é, principalmente, a proteção da paisagem, no trecho conquistado ao mar, compreendido entre a praia de Santa Luzia e o Morro da Viúva. E, em relação tanto à utilidade quanto à oportunidade do tombamento para esse fim, quer parecer-me que não poderá pairar dúvida alguma. Opino, pois, de acordo com o órgão competente desta Diretoria, pela conveniência da inscrição do Parque do Flamengo no Livro do Tombo Paisagístico. ${ }^{34}$ 
Para Rodrigo Mello Franco de Andrade, se o parque ainda estava por ser construído, a paisagem - dada pela natureza no trecho aterrado pelo homem estava lá, e a ela, então, ele conferia valor de patrimônio. Na sequência, o diretor indicou o conselheiro Paulo Santos para relatar o processo. Ele deveria apresentar seu parecer sobre o assunto, para subsidiar a decisão final do Conselho, a ser tomada em reunião plenária, com base na sua argumentação como conselheiro relator. Em seu parecer, de 7/41965, Paulo Santos, inicialmente, descreveu o conteúdo do processo, sintetizou o pensamento do diretor-geral e, em seguida, apresentou sua opinião sobre o caso. Paulo Santos argumentou a favor do tombamento ao mesmo tempo em que respondia à afirmação de Lota de Macedo Soares, ao dizer que:

O projeto urbanístico e arquitetônico de Affonso Reidy e sua equipe e os jardins de Roberto Burle Marx formam conjunto de grande beleza e interesse social de que muito pode orgulhar-se a cidade do Rio de Janeiro, e que deve ser preservado, não só para que não seja alterado no seu traçado pelas administrações futuras, como para ser convenientemente conservado. ${ }^{35}$

Preocupado também com os riscos de exploração indevida do parque, que poderiam vir a modificar o projeto e com isso "sacrificar" sua beleza e integridade, afirma:

O perigo maior consiste na inclusão futura na área ajardinada de pavilhões de diversões, restaurantes, cinemas e quejandas edificações, como assim de bustos de figuras nacionais, etc. - inclusão que tendo a justificá-la o interesse prático ou cívico das iniciativas poderá sacrificar irremediavelmente a beleza do conjunto. [...] Os pavilhões erguidos ou por erguer no Aterro [que integram o projeto original] já representam, a meu ver, o máximo que a área comporta e podem justificar-se menos pela sua finalidade prática do que em razão de conferirem escala urbanística ao conjunto, mas mesmo esta será sacrificada se não houver contenção na distribuição dos valores que a determinaram. [...] Por tudo isso, a ideia do Tombamento me parece a única capaz de preservar esses valores. ${ }^{36}$

Os valores de patrimônio conferidos ao novo Parque, para justificar sua premente proteção, remetem aos seus atributos estéticos e formais - de grande beleza -, e a necessidade de tombá-lo é preventiva, pois diz respeito à segurança da sua permanência no tempo, para orgulho da cidade, para evitar o "perigo maior" de alterações da obra de arte que acabara de ser projetada, com intervenções indesejáveis, que quebrariam a "beleza do conjunto". A proteção de seus pavilhões e edificações projetadas (ainda por construir) justifica-se não propriamente pela sua "finalidade prática", mas "em razão de conferirem escala urbanística ao conjunto". O debate anteriormente levantado acerca do possível prejuízo que a redução das vias poderia causar não aparece na documentação do processo. 
37. Ver Ata da $44^{\mathrm{a}}$ reunião do Conselho Consultivo do Patrimônio Histórico e Artístico Nacional (1965). Sobre o funcionamento do Conselho Consultivo, ver Márcia Regina Romeiro Chuva (2014).

38. Ver Flávia Brito do Nascimento (2016).

39. Ver Flávia Brito do Nascimento (2016, p. 164-165).

40. Ver parecer de Renato Soeiro apud Flávia Brito do Nascimento (2016, p. 99). Ver também parecer de Lucio Costa no Processo n. 672-T-62 - Catedral de Brasília, reproduzido em José Pessôa (1999).

41. Ver Simoni Scifoni (2006).

42. Ver Cristiane Magalhães (2015).
Embora o uso a que se destina tenha sido enaltecido pelos pareceres das diferentes instâncias da DPHAN como obra de "interesse social", é o projeto urbanístico arquitetônico original acabado, completo e pleno que repercute nos argumentos: "a ideia do Tombamento me parece a única capaz de preservar esses valores". No final de seu parecer, o conselheiro Paulo Santos sugeriu a inclusão da "área marítima abrangida pelo Parque até 100 metros da praia, em toda a extensão, a fim de evitar se possam erguer ali futuras construções espúrias que igualmente poderão sacrificar a beleza do conjunto" no perímetro a ser tombado. Aterro como patrimônio é assim, também, fronteira conquistada que esbarra e avança sobre o mar.

Em reunião realizada em 20 de abril de 1965, o Conselho Consultivo da DPHAN aprovou por unanimidade o tombamento do Parque do Flamengo, tal como proposto por Paulo Santos, com a inclusão da área maríima ${ }^{37} \bigcirc$ Parque foi tombado em nível nacional pelo valor estético, arquitetônico e paisagístico a ele conferido.

Para Flávia Nascimento, os arquitetos modernistas lançaram mão do tombamento de suas obras como recurso de afirmação, para garantir a sua materialidade e comprovar a originalidade da arquitetura moderna não somente às gerações futuras, mas para protegê-las das ameaças no presente. ${ }^{38}$ Isso ocorreu nos primeiros tombamentos de bens de arquitetura moderna, que se referem, segundo a autora, a um ciclo que se encerra com o tombamento da Catedral de Brasília, em 1967. Novos tombamentos desse tipo voltariam a ser realizados pelo órgão federal de patrimônio somente a partir de 1984, com outras motivações, em conjuntura distinta. ${ }^{39}$

O tombamento da Catedral de Brasília também se deu antes da conclusão das obras - prerrogativa já inaugurada com o tombamento do Aterro do Flamengo. Nos dois casos, as justificativas de valor foram tanto de natureza preventiva quanto paisagística, com o argumento de que já faziam parte da paisagem urbana, ${ }^{40}$ ou, quiçá, haviam construído essa paisagem, além, é claro, do valor estético da obra de arte.

Vale destacar que o Decreto-lei n. 25/37, que organiza a proteção do patrimônio histórico e artístico nacional, já previa a possibilidade de tombamento de monumentos naturais e o reconhecimento de valores paisagísticos, tendo sido pioneiro nesse tipo de ação. ${ }^{41}$ Contudo, em relação ao tombamento de jardins históricos nesse período, Cristiane Magalhães observa uma postura de valorização dos aspectos estéticos do mobiliário dos jardins e não propriamente da sua massa vegetal, sequer mencionada em diversos casos. ${ }^{42}$ Por isso mesmo, os primeiros tombamentos de jardins deram-se com base em valores históricos e artísticos e foram inscritos nos Livros de Tombo Histórico ou das Belas-Artes. 
Segundo essa autora, o tombamento do Parque do Flamengo em 1965 inaugurou um novo procedimento de valorização de bens classificados como paisagísticos, na medida em que a maioria deles passou a ser inscrita também no Livro do Tombo Arqueológico, Etnográfico e Paisagístico. ${ }^{43}$ Nenhuma normativa, regulamento, parecer, ou produção reflexiva, contudo, foi identificada como indutora dessa nova atitude.

É fato que Lota de Macedo Soares e Rodrigo Mello Franco de Andrade enfatizaram a paisagem como um valor, conforme destacamos anteriormente. Contudo, a perspectiva estética não foi ignorada na argumentação do conselheiro Paulo Santos, tendo sido mesmo decisiva na atribuição de valor de patrimônio ao Parque. Nesse sentido, entendemos que o Parque do Flamengo se encontra no limiar relativo aos dois modos de operar a preservação de jardins no Iphan.

Verificamos que, considerando tanto a periodização proposta por Cristiane Magalhães quanto aquela apresentada por Flávia Nascimento, houve uma inflexão nas políticas de patrimônio nos anos 1960. Esse momento tem sido interpretado, sob diferentes pontos de vista, como o momento em que a temática do turismo ganha relevância, e à argumentação da preservação pelos aspectos históricos e artísticos acrescenta-se sua capacidade de agregar usos voltados ao lazer e a circulação de pessoas, além de se tornarem produtos a serem consumidos. ${ }^{44}$ Leila Aguiar também identifica nos anos 1960 uma importante virada nas políticas de patrimônio no Brasil, tendo em vista o incremento do turismo, com a criação da Embratur e outros dispositivos com vistas à formulação de políticas associadas de patrimônio e turismo, sendo o Rio de Janeiro um dos principais destinos em foco. ${ }^{45}$

As motivações sociais para a construção do Aterro, destacadas também nos argumentos para a sua patrimonialização, estavam relacionadas às funções previstas para ele, voltadas para as novas necessidades da vida moderna nos grandes centros urbanos, que incluem a diversão, a recreação, o desfrute de horas livres e tudo o que pode estar relacionado ao lazer (e também ao turismo) de modo disciplinado, como descanso merecido por conta das horas de trabalho. ${ }^{46}$

Verificamos aspectos relativos a essas novas demandas nos valores que compunham os atributos do Aterro e nas expectativas criadas em torno dele em artigos sobre o projeto, publicados em duas revistas especializadas de arquitetura.

A revista Módulo47 publicou, em agosto de 1964, artigo do engenheiro civil Enaldo Cravo Peixoto. Colega de Reidy nos quadros da Prefeitura, ele integrou - Grupo de Trabalho coordenado por Lota de Macedo Soares, além de ter ocupado o importante cargo de secretário de obras do estado da Guanabara no governo de Carlos Lacerda. Para Enaldo Peixoto, o Aterro do Flamengo se tornaria "o grande pulmão da cidade". Com expectativas sobre o Parque, destacou
43. Os tombamentos do Bosque Schmalz, em Joinville, do Passeio Público de Fortaleza (ambos em 1965) e da Floresta da Tijuca (em 1967) compõem, com o Parque do Flamengo, esse primeiro grupo de inscrições de bens paisagísticos no Livro de Tombo Arqueológico, Etnográfico e Paisagístico. Ver Cristiane Magalhães (2015).

44. Ver Ulpiano Toledo Bezerra de Meneses (2009), Leila Bianchi Aguiar (2006) e Cláudia Feierabend Baeta Leal (2009).

45. Ver Leila Bianchi Aguiar (2006).

46. Ver Maria das Graças de Menezes Paiva (1995) e Leila Bianchi Aguiar (2006).

47. Ver Enaldo Cravo Peixoto (1964). 
48. Cf. Enaldo Cravo Peixoto $(1964$, p. 28$)$.

49. Cf. Enaldo Cravo Peixoto $(1964$, p. 31$)$.

50. Cf. Enaldo Cravo Peixoto $(1964$, p. 31$)$.

51. Após o desmonte, restou apenas um pequeno pedaço do morro, com o convento e a Igreja de Santo Antônio, tombados pelo SPHAN em 1938.

52. Ver Virgínia Pontual e Rosane Piccolo (2008). aspectos relativos à qualidade de vida ambiental da cidade do Rio de Janeiro, enfatizando que, graças à sua localização central,

não beneficiará apenas a população da zona sul, porque se situa na zona central e representa o traço de união entre as regiões mais populosas da cidade"; também afirmou que, "de todas as obras do governo de Carlos Lacerda, pela atração exercida sobre a população, será a obra mais estimada. ${ }^{48}$

Apontou ainda que os elementos arquitetônicos ali existentes, "duas grandes obras de arquitetura, o MAM e o Monumento aos Mortos na Segunda Guerra, harmonizam com a paisagem marítima da baía". Segundo o mesmo artigo,

Essa área apresenta qualidades extraordinárias. Beneficia-se de uma situação privilegiada, reunindo a um só tempo o cenário espetacular constituído pelo mar e pelas montanhas que a envolvem, situando-se praticamente, no centro da cidade, com acesso igualmente fácil para todos os bairros. ${ }^{49}$

Vale destacar que o processo então em curso de afastamento das populações pobres do centro e da zona sul da cidade para zonas periféricas, como vimos anteriormente, não se coaduna com a afirmativa acima, o que evidencia claramente como os interesses dos grupos hegemônicos, social, econômica e politicamente, se transfiguram em interesses de todos, em diferentes canais de produção de discursos e de comunicação.

artigo ressaltou que o desmonte do Morro de Santo Antônio,

proporcionou duas grandes áreas de excepcional interesse no centro da cidade: uma resultante do desmonte propriamente dito, com área de 30 hectares, no local mais valorizado da cidade; outra obtida pelo aterro [...] de uma faixa ao longo da antiga Avenida Beira Mar, do Aeroporto Santos Dumont à Praia de Botafogo. ${ }^{50}$

Desse modo, as vantagens destacadas acerca do desmonte do Morro de Santo Antônio foram não somente a oportunidade de "dotar a cidade de um parque ativo", mas especialmente por ter criado uma nova área no centro da cidade de alto valor comercial. ${ }^{51}$ No vazio criado com o desmonte do Morro de Santo Antônio, deu-se o aproveitamento imobiliário por meio da abertura da Avenida Chile e foi construída a Catedral Metropolitana do Rio de Janeiro.

O pensamento dominante parece ser o de que a cidade precisa se expandir. Se as grandes cidades não poderiam ser impedidas de crescer, era preciso conciliar o patrimônio com a cidade moderna. ${ }^{52}$ Nessa visão, o recurso à patrimonialização pode ser acionado em situações específicas, para ir de encontro 
às pressões da especulação imobiliária. Esta última é recorrentemente referida como uma entidade maligna que paira sobre a cidade, sem que seus agentes sejam, de algum modo, nomeados.

No governo Lacerda, esses agentes foram beneficiados e fortalecidos pela invenção de novas terras no centro e na zona sul, por meio de desmontes de morros e favelas. Desse modo, novos lotes são criados e sobre eles projeta-se um valor (isto é, o que ele pode vir a ser ou o que se especula sobre ele), bem como confirma-se um claro plano de distribuição social hierarquizada do espaço da cidade, com a supervalorização dessas zonas, como se pode ver pelo conjunto de obras realizadas. ${ }^{53}$ As duas ações (desmonte e aterro/parque) são etapas conciliadas de um planejamento realizado de modo articulado em toda a cidade pelo governador Carlos Lacerda.

artigo publicado na Arquitetura, revista do Instituto dos Arquitetos do Brasil, em dezembro de 1964, é de autoria de Ethel Bauzer Medeiros, mencionada anteriormente, que foi responsável pelo planejamento das áreas de recreação e lazer do Parque. Para ela, é a localização geográfica do Parque que se destaca como "sua característica mais digna de nota", como um "lugar para atividades recreativas necessárias ao habitante das grandes cidades". Com ênfase numa abordagem sociológica, refere-se às dificuldades inerentes à vida nas concentrações urbanas em que se disputa palmo a palmo o espaço para viver. Tudo isso torna a recreação um serviço público necessário. Para analisar as vantagens da criação do Parque, o artigo embasa-se na nova sociologia então em voga nos EUA, a comprovar que "repouso e diversão nos grandes centros, beneficia a sociedade e não apenas o indivíduo, e aumenta sua produtividade: o oferecimento de facilidades para recreação ao ar livre resulta em benefícios econômicos para a sociedade". ${ }^{54}$

A perspectiva estética destacada no parecer de tombamento do conselheiro arquiteto Paulo Santos, anteriormente citado, está também presente no artigo de Ethel Medeiros, ao referir-se ao paisagismo na perspectiva dos usuários do parque. Segundo Medeiros, seriam trazidas plantas "de diversas regiões do país para o Horto-Piloto, onde se aclimatam antes do plantio definitivo, salientando-se a preocupação em utilizar espécies variadas, com floração em épocas distintas, a fim de assegurar a presença constante de flores". $55 \bigcirc$ foco, portanto, da preservação do jardim era o seu embelezamento com a presença permanente de flores, para o deleite e a fruição dos seus usuários.

pensamento disseminado na época, nos dois artigos citados, é o do jardim como parte que integra o projeto urbanístico arquitetônico. A conservação da massa vegetal está subordinada à fruição estética.
53. Ver Maurício de Abreu (1988).

54. Cf. Ethel Bauzer Medeiros (1964, p. 19). Podemos compreender a invenção desses novos hábitos como parte de processos de longa duração de domesticação de corpos, regramento do uso do tempo livre e do espaço público. Ver Norbert Elias (1989), dentre outros.

55. Cf. Ethel Bauzer Medeiros (1964, p. 19). 
56. Ver Olivier Rialland (2000).

57. O dossiê de candidatura foi publicado pelo Comitê técnico da candidatura do Rio a patrimônio mundial com o título Dossiê do Rio de Janeiro: paisagens cariocas entre o mar e a montanha [doravante denominado Dossiê Rio (2011)].

58. Cf. Ata da $23^{a}$ reunião do Conselho Consultivo do Patrimônio Cultural (2000, p. 21-22).
A concepção de paisagem que predomina com o novo procedimento de inscrição dos jardins e bens paisagísticos no Livro de Tombo Arqueológico, Etnográfico e Paisagístico, ao menos no caso do Aterro do Flamengo, parece ser a mesma destacada por Lota de Macedo Soares e Rodrigo Mello Franco de Andrade, em que prevalece a fruição estética e formal, embora já se vislumbrasse um valor social - que nos remete às funções do Parque e aos sujeitos que por meio de usos e apropriações múltiplas the conferem sentidos diversos.

Os debates sobre a preservação de jardins públicos apontam novas ênfases, na atualidade, ao considerar os usos e as apropriações dos seus frequentadores que, muitas vezes, sentem-se ameaçados e organizam-se em sua defesa, bem como as características de sua massa vegetal, composta de elementos vivos, que se transformam no tempo e no espaço. A história do jardim é compreendida como a história da sua vegetação, devendo ser investigada em sua trajetória singular e integração ao jardim. ${ }^{56}$

Examinaremos, a seguir, como se colocaram os debates sobre preservação dos jardins históricos no Conselho Consultivo do Patrimônio Cultural, a partir dos anos 2000. Serão explorados, especialmente, os valores acionados na preservação do Aterro do Flamengo no contexto em que o Rio de Janeiro torna-se palco dos grandes eventos esportivos (os Jogos Pan-americanos em 2007 e os Jogos Olímpicos em 2016) e recebe o tífulo de Patrimônio Mundial na categoria de Paisagem Cultural, ao passo que a agenda contemporânea do campo do patrimônio coloca na ordem do dia o debate sobre a função social do patrimônio. ${ }^{57}$

\section{PARQUE DO FLAMENGO: PATRIMÔNIO MODERNO NA PAISAGEM DO RIO}

Em 2000, na ocasião em que o Conselho Consultivo discutia o tombamento do sítio do paisagista Roberto Burle Marx, no Rio de Janeiro, o conselheiro Nestor Goulart Reis Filho fez algumas ponderações a respeito da preservação dos jardins no Brasil. Ele questionou os objetivos do tombamento dos jardins, tendo em vista os procedimentos para a sua identificação e mesmo a sua gestão. Goulart afirma:

Nós tombamos a casa, os quadros, os objetos e o ambiente, que daqui a cem anos certamente estarão lá [do sítio de Roberto Burle Marx]. Uma parte que não vi explicitada, talvez esteja implícita e eu não entenda, é exatamente o jardim. Mais de uma vez temos falado em jardins e tombamento de jardins. [...] A pergunta é a seguinte: quando vamos começar a tombar jardins no Brasil com conhecimento de causa e controle técnico? [...] $\bigcirc$ jardim é uma coisa muito fácil de comer pelas bordas. [...] Temos um registro, alguém vai acompanhar a sua manutenção? 58 
Partindo do pressuposto de que a gestão do bem tombado deve ser orientada pelos valores a ele atribuídos, bem como pelo conhecimento do seu funcionamento, modo de vida e sentidos da sua perpetuação e continuidade, Nestor Goulart criticou a persistência em se tratar jardins e parques - bens paisagísticos - de modo subordinado ao projeto de arquitetura, sem priorizar a sua massa vegetal.

Embora os tombamentos tenham passado a valorizar o aspecto paisagístico ao serem inscritos no Livro de Tombo Arqueológico, Etnográfico e Paisagístico, como vimos, as estratégias para sua identificação e gestão revelavam, segundo Nestor Goulart, que a perspectiva arquitetônica ainda se impunha: jardins vistos como peças que compõem um projeto de paisagismo arquitetônico. $\bigcirc$ desconhecimento acerca das especificidades desse tipo de bem o coloca à mercê da destruição, pois não se sabe exatamente o que defender, correndo o risco de ser devorado pelas beiradas.

Vejamos, então, as tensões e os argumentos de valor em torno da preservação do Parque do Flamengo nessa nova conjuntura.

Após seu tombamento, em 1965, o Parque retornou à pauta do Conselho Consultivo em 1988, para que fosse avaliada uma proposta de construção na área da Marina da Glória, que alteraria seu projeto. Na ocasião, o Conselho decidiu rejeitar a construção de qualquer edificação não prevista no projeto original de Reidy e Burle Marx, garantindo a manutenção de toda sua área como non aedificandi. Em 1998, o Conselho foi novamente convocado a opinar sobre projetos na mesma zona do Parque e manteve seu entendimento sobre o bem tombado, assim como a decisão tomada dez anos antes. ${ }^{59}$

Em 2006, com a perspectiva de realização dos Jogos Pan-americanos na cidade, o Parque voltava à cena no Conselho, em função de novas pressões imobiliárias sobre o mesmo local - a Marina da Glória. Conforme relato do então presidente do Iphan, Luis Fernando de Almeida, ao Conselho Consultivo, 60 o Instituto era acusado de impedir a futura realização das provas de iatismo na Baía de Guanabara durante os Jogos, porque havia rejeitado a construção de uma edificação no local. Na mesma reunião, foi apresentada a carta da Associação Moradia Digna nas Áreas Centrais, que congrega moradores de baixa renda da área central do Rio, enviada ao Iphan. Eles sentiam-se ameaçados pelo risco de uma progressiva privatização daquela área:

Somos usuários assíduos do nosso Parque do Flamengo, que consideramos principal espaço de lazer para nossas as famílias, pela proximidade da nossa moradia e acesso democrático e gratuito que temos a esse belíssimo lugar. Por essa razão, nosso o repúdio à privatização do espaço hoje ocupado pela Marina da Glória, cuja ampliação implicará em grandes
59. A respeito das pressões e transformações sobre o Parque do Flamengo, ver Ana Rosa de Oliveira e Cláudia Maria Girão Barroso (2006) e Cláudia Girão (2011a, 2011b). Ver também G1 Rio de Janeiro (2016).

60. Ver Ata da $50^{a}$ reunião do Conselho Consultivo do Patrimônio Cultural (2006). 
61. Carta de Maria Guilhermina de Alexandre, presidente da Associação Moradia Digna nas Áreas Centrais. Cf. Ata da $50^{\mathrm{a}}$ reunião do Conselho Consultivo do Patrimônio Cultural (2006).

62. Ver Cláudia Girão (2011a, 2011b).

63. Ver Gaelle Gillot (2005).

64. Ver, dentre outros, Jurema Kopke Eis Arnaut (1984), Márcia Regina Romeiro Chuva (2012), Maria Cecília Londres Fonseca (1997 e 2003), Paulo Cesar Garcez Marins (2016) e Lia Motta (2017).

65. Ver Cláudia Girão (2011a, 2011b) e Ana Rosa de Oliveira e Cláudia Maria Girão Barroso (2006). Ver também G1 Rio de Janeiro (2016). construções, na perda de áreas, bosques, com cercamento de espaços e da paisagem, beneficiando os ricos e excluindo, mais ainda, a população pobre da cidade. ${ }^{61}$

A demanda da Associação nos mostra representações em disputa sobre os destinos do Parque, que vemos como indícios de um debate sobre a função social do patrimônio, num jogo de forças bastante desigual. É o que aponta o estudo de Cláudia Girão Barroso sobre o Parque do Aterro do Flamengo, ao revelar, na verdade, a intensidade das transformações que o projeto original sofreu ao longo do tempo, tanto na sua massa vegetal quanto no projeto arquitetônico urbanístico, no sentido da privatização progressiva de alguns setores, ainda que os discursos de preservação do parque tenham se pautado na manutenção do seu caráter público e das áreas livres non aedificandi. 62

O caso do Jardin d'Essais em Rabat-Salé, no Marrocos, apresentado por Gaëlle Gillot, ${ }^{63}$ parece ser, ao contrário, um exemplo de preservação de jardim histórico resultante da mobilização popular. Esse jardim encontrava-se abandonado até o momento em que a ameaça concreta de construção de um edifício no local levou os moradores da vizinhança a se organizarem em uma associação para lutar contra a sua destruição. Eles acabaram por encontrar na patrimonialização do jardim o caminho para, nas palavras de Gillot, combater a especulação imobiliária: em 1992, o Jardin d'Essais foi inscrito na Lista de Patrimônio Nacional no Marrocos, e setores da universidade assumiram o compromisso de reorganizar o lugar como um jardim botânico, voltado para a investigação.

Interessa-nos ressaltar nesse exemplo a apropriação da preservação do patrimônio por movimentos sociais urbanos como instrumento de lutas nas querelas sobre direito à cidade, pensado aqui como o direito de morar dignamente, de ir e vir, de dispor de áreas públicas de lazer, trabalho e serviços próximos à moradia.

A historiografia do campo do patrimônio no Brasil tem destacado, recorrentemente, os anos 1980 como momento em que tal apropriação começa a acontecer, apontando vários exemplos que associam as lutas por qualidade de vida urbana à preservação do patrimônio. ${ }^{64}$ Vimos que, desde os anos 1980, a preservação do Parque do Flamengo sofre as pressões advindas dessas disputas urbanas, sendo o recurso ao patrimônio acionado por diferentes lados nem sempre ligados aos movimentos sociais. $\bigcirc$ foco de maior tensão tem sido em torno da Marina da Glória. Efetivamente, a Prefeitura inaugurou ali, em 2016, as rampas para o livre acesso de barcos à Baía de Guanabara, mas, em contrapartida, uma nova edificação com restaurantes e outros serviços ocupou o local. ${ }^{65} \mathrm{~A}$ pressão imobiliária na área da Marina reforça a tendência a uma 
espécie de gentrificação do uso do espaço público, ${ }^{66}$ explorado, comercialmente, para um público elitizado. ${ }^{67}$

$\bigcirc$ Rio, portanto, permaneceu submetido a uma série de tensões e intervenções urbanas, ao longo dos anos 2000. Foi nesse contexto que a Prefeitura, motivada pelos Jogos Olímpicos que sediaria em 2016, coordenou o encaminhamento da candidatura do Rio de Janeiro a Patrimônio Mundial da Unesco, na categoria de paisagem cultural.

No Conselho Consultivo do Patrimônio Cultural, em 2006, 68 o conselheiro Ulpiano Bezerra de Meneses faz críticas à noção de paisagem cultural, evidenciando as tensões que envolvem o uso dessa categoria e, por conseguinte, seus efeitos sobre a própria candidatura do Rio de Janeiro a Patrimônio Mundial.

Como afirma Ulpiano Meneses, toda paisagem resulta da intervenção humana e, portanto, ela é cultural por definição, dispensando-se a necessidade do adjetivo cultural. A paisagem não se confunde com o fato geomorfológico, "a paisagem é o fato geomorfológico culturalmente apropriado". Desse modo, ele explica o que entende por "intervenção humana":

Intervenção humana não se resume apenas na intervenção da forma. A intervenção humana no fato geomorfológico se faz em três dimensões bastante diferentes que podem ser articuladas ou não: apropriação da forma, aí existe alteração da própria substância; apropriação da função e apropriação de sentido. ${ }^{69}$

Por conta dessa crítica, ele esclarece algumas implicações danosas que o conceito de paisagem cultural pode provocar:

Nós poderemos ter em pouquíssimo tempo a seguinte dualidade: o patrimônio cultural Imaterial, que é o lugar dos vivos, dos atuantes da cultura, como coisa em ação, e vai ser o Patrimônio das Comunidades; em outro compartimento, outra gaveta vamos ter o cemitério cultural, que vai ser o patrimônio Cultural Material, o patrimônio dos lugares de memória. [...] Com isso estaremos excluindo o patrimônio de onde ele tem o verdadeiro sentido para a vida humana: no cotidiano e no universo do trabalho. ${ }^{70}$

Essa dualidade que persiste no conceito de paisagem cultural funda-se numa falsa questão, segundo Meneses, que é a separação entre corpo e alma, forma e função, matéria e sentido, natureza e cultura. Para superá-la é necessário alcançar os sujeitos que produzem, fruem e usufruem a paisagem, e assim perceber as funções e os sentidos por meio dos quais as paisagens são apropriadas.

A crítica a essa separação tem sido abordada especialmente nos debates sobre a função social do patrimônio. ${ }^{71} \mathrm{Na}$ Conferência Magna que fez na abertura do $1^{\circ}$ Fórum Nacional do Patrimônio Cultural, em 2009, na cidade de Ouro Preto,
66. Para uma história do conceito de gentrificação urbana, ver Silvana Rubino (2009).

67. Alguns usos populares do Parque foram apresentados como problemas, como fatores prejudiciais à sua conservação, dentre os quais o "uso de churrasqueiras e a presença de vendedores ambulantes". Afirma-se que o "Plano Diretor do parque irá definir um regulamento para evitar práticas inadequadas". Cf. Dossiê Rio (2011, p. 66).

68. Ata da $50^{\mathrm{a}}$ reunião do Conselho Consultivo do Patrimônio Cultural (2006).

69. Ata da $50^{a}$ reunião do Conselho Consultivo do $\mathrm{Pa}$ trimônio Cultural (2006, p. 34). Grifos nossos.

70. Ata da $50^{\mathrm{a}}$ reunião do Conselho Consultivo do Patrimônio Cultural (2006, p. 35).

71. Para o assunto, ver Márcia Regina Romeiro Chuva (2012) e Ulpiano Toledo Bezerra de Meneses (2009). Sobre a função social do patrimônio, ver também Maria Cecília Londres Fonseca (2003). 
72. Cf. Ulpiano Toledo Bezerra de Meneses (2009, p. 39).

73. Ver Dossiê Rio (2011).

74. Essa imagem encontra-se em diversas formas de linguagem. De tal forma reproduzida, está incorporada como dada. A título ilustrativo, destacamos o personagem Zé Carioca, criado pelos estúdios Walt Disney nos anos 1940, e o filme de animação Rio, the movie, dirigido por Carlos Saldanha e produzido pela 20th Century Fox e Blue Sky Studios em 2011.

75. Cf. Dossiê Rio (2011, p. 16-18).
Ulpiano Meneses voltou a criticar tal divisão, referindo-se ao patrimônio material e imaterial. Entendemos, como Meneses, que o campo do patrimônio é eminentemente político, "no sentido da polis [...] aquilo que era gerido compartilhadamente pelos cidadãos". Lugar de valores que precisam ser "enunciados, explicitados, fundamentados e podem ser propostos, recusados, transformados - não impostos". ${ }^{72}$ Logo, a separação entre natureza e cultura não faz sentido no âmbito do patrimônio, pois ele está remetido às apropriações e não à essência das coisas.

Qual seria, então, o papel dado ao Parque do Aterro do Flamengo na proposta que levou à inclusão do Rio de Janeiro na Lista de Patrimônio Mundial da Unesco, na categoria de paisagem cultural?

Não cabe no escopo deste artigo examinar em detalhe o Dossiê Rio de Janeiro: paisagens cariocas entre o mar e a montanha ${ }^{73}$ de candidatura da cidade ao título de Patrimônio Mundial da Unesco na categoria de paisagem cultural, ou os debates conceituais travados em sua montagem, que envolveu diferentes setores da sociedade e do poder público. Buscamos apenas compreender o destaque dado ao Parque do Flamengo nos argumentos discursivos que construíram a imagem da cidade no referido Dossiê que, como veremos, privilegiou sua beleza natural e a exuberante paisagem.

Tal imagem tem sido forjada e reproduzida há quase um século por diferentes narrativas, linguagens e canais de divulgação e disseminação de ideias, tendo se tornado, em alguns contextos, a própria representação da nação brasileira. ${ }^{74}$ Podemos dizer que os tombamentos de bens naturais nas áreas centro e sul da cidade, realizados pelo Iphan, também contribuíram para a construção dessa imagem: em 1938, houve o tombamento cuja inscrição diz "Morros da cidade" do Rio de Janeiro; em 1973, são tombados nomeadamente: Morro do Pão de Açúcar, Morro da Urca, Morro da Babilônia, Corcovado, Dois Irmãos, Pedra da Gávea, Morro Cara de Cão e o Horto Florestal, como bens paisagísticos.

O Parque do Flamengo foi explorado de diferentes formas na construção dos sentidos e valores listados na proposta aprovada pela Unesco: como "obraprima de um gênio criativo humano", especialmente em função do projeto paisagístico de Roberto Burle Marx; como "uma das mais bem-sucedidas realizações do urbanismo moderno", especialmente valorizado no Dossiê e associado à ainda hegemônica escola carioca; como "paisagismo excepcional", "ícone do paisagismo modernista brasileiro". 75

No Dossiê da candidatura, o Parque do Flamengo foi colocado dentre os cinco elementos que garantiriam os atributos de "autenticidade e integridade" na 
paisagem cultural do Rio de Janeiro, ao lado do Parque Nacional da Tijuca; Jardim Botânico; Entrada da Baía: Fortes históricos, Pão de Açúcar e Enseada de Botafogo; e Praia de Copacabana. Todos eles, como se pode notar, compostos de vegetação ou inseridos em contextos naturais, como o mar e a montanha. Esses elementos compõem os setores A e B. Já o Setor C refere-se à "paisagem urbana" e foi definido como "zona de amortecimento". 76

Vale ressaltar que todas as áreas incluídas no sítio delimitado como Paisagem Cultural do Rio de Janeiro são de propriedade da República Federativa do Brasil, tratando-se de uma estratégia para viabilizar a execução da proposta. Contudo, isso não significa que tais áreas estejam livres dos problemas sociais e urbanos que tomam conta da cidade, e pudemos identificar alguns dos seus indícios no próprio Dossiê.

Percebemos, por exemplo, que foi adotado o termo "comunidade" para se referir às favelas como locais de moradia, indo de encontro às lutas do movimento social contra o estigma da favela e dos favelados e pela ressignificação cultural desses termos. ${ }^{77}$ Por outro lado, encontramos o uso do termo favela para se referir ao modo de ocupação irregular das encostas de diversos morros da cidade, nas referidas zonas de amortecimento do Setor C. Observamos, também, o uso sempre associado das palavras "moradores e turistas", para se referir aos usuários dos sítios no tempo presente, sem serem feitas distinções entre essas categorias, ou mesmo no interior de cada uma delas, parecendo que seus interesses, demandas ou necessidades são similares ou unívocos. A categoria "moradores" aparece apenas nas referências a costumes do tempo passado.

Verificamos, pois, que o Dossiê não se deteve no cotidiano da complexa vida na cidade e nos modos de morar de uma população, que, em 2017, já ultrapassa os 6 milhões de habitantes. As referências a essa população aparecem como uma idealização: "o homem carioca". 78

P Parque do Flamengo é citado inúmeras vezes, especialmente por seus atributos formais - paisagístico, natural, arquitetônico -, como obra de Reidy e Burle Marx. Mas a riqueza das apropriações multifacetadas desse parque tão moderno e tão popular do Rio de Janeiro - pequena mostra das práticas culturais dos sujeitos que lutam pelo direito à cidade - não foi explorada. Desse modo, um dos valores que haviam motivado o seu tombamento, o valor social - ao lado do paisagístico e do estético -, poderia ter sido retomado, num esforço de reconciliação entre cidadãos e as imagens/representações da sua cidade.

As negociações para a construção de um consenso em torno da candidatura do Rio ao título de Patrimônio Mundial na categoria de Paisagem Cultural, evidentemente, foram atingidas pelas tensões que, paralelamente, se intensificaram
76. Cf. Dossiê Rio (2011, p. 8).

77. Como se pode ver na referência ao intenso turismo no Parque Nacional, para apontar que "essa atividade garante renda a cerca de $30 \%$ dos moradores das $c 0$ munidades do seu entorno, segundo dados do relatório de atividades 2000-2008 da empresa de turismo do município do Rio de Janeiro (RIOTUR)". Cf. Dossiê Rio (2011, p. 83), grifo nosso.

78. Cf. Dossiê Rio (2011, p. 21). 
79. Ver Maria Goretti Tavares e Cleber Augusto Trindade Castro (2016).

80. Ver Flora Cardoso (2016).

81. Esse aspecto, segundo Flora Cardoso, motivou a rejeição da candidatura de Buenos Aires pela Unesco. Ver Flora Cardoso (2016, p. 98).

82. Cf. Silvana Rubino (2009, p. 37). no contexto de reformas urbanas empreendidas para sediar as Olimpíadas. Vimos, mais uma vez, que o recurso ao patrimônio pode ser muitas vezes acionado, mas nem sempre pelo mesmo lado nas lutas sobre o projeto de cidade que se deseja implantar. ${ }^{79}$ No Dossiê da referida candidatura fica evidente a intenção de invisibilizar as áreas urbanas, em especial as favelas, ora chamadas de "comunidades", ora colocadas nas "zonas de amortecimento", e das duas formas não percebidas pela força de suas contradições e complexidade de seus problemas. Para Flora Cardoso, ${ }^{80}$ essa escolha agradou os setores da Unesco ligados à Convenção do Patrimônio Mundial, que não têm reconhecido características urbanas em paisagens de valor patrimonial, ${ }^{81}$ como se a característica urbana dessa paisagem - a paisagem urbana - em si indicasse a inexistência de valor de patrimônio. Retomamos aqui as lições de Ulpiano Meneses: afinal, falamos em patrimônio para quem, paisagem de quem?

Mencionamos, anteriormente, a gentrificação de usos que tem alterado o cotidiano e o público do Aterro. É possível também supor que a partir da instalação do Parque do Flamengo deu-se, paulatinamente, a valorização imobiliária na região. Contudo, não vamos compreender essas dinâmicas se pensá-las apenas como uma política de exclusão. Como tratou Silvana Rubino, o enobrecimento "é uma faceta delicada das dinâmicas urbanas, uma vez que quanto mais afirma $\circ$ valor e o papel da cidade, lembra que $\mathrm{o}$ ar da cidade liberta apenas aqueles que sabem e podem nela viver". 82

\section{LIMIARES: NA ARENA DO PATRIMÔNIO}

Não basta apontar a especulação imobiliária como o tradicional inimigo do "patrimônio" em sua mítica luta travada na cidade, se não se colocar em foco os interesses, as visões e as posições em disputa na gestão da cidade patrimonializada. Para isso, os diferentes agentes que constituem o multifacetado campo do patrimônio devem ser nomeados; os diversos beneficiários da patrimonialização, tal como ela tem sido operada em cada situação específica, devem ser conhecidos, identificados, explicitados, assim como as várias camadas de valores, sentidos e interesses daqueles que atuam nessa arena de conflitos, que é o campo do patrimônio.

$\mathrm{Na}$ imagem da cidade do Rio de Janeiro priorizada na candidatura à Patrimônio Mundial na categoria de paisagem cultural, a ênfase nos aspectos plásticos, estéticos, paisagísticos - tais como aqueles apontados no Parque do Flamengo - prevaleceu sobre o reconhecimento das suas populações e dos seus 
diferentes modos de morar - nas favelas e fora delas -, construídos cotidianamente na expectativa de qualificar a vida na cidade.

Nossa leitura sobre o Parque do Flamengo como patrimônio estético, social e paisagístico do Rio nos levou a refletir sobre a função social do patrimônio associada ao direito à cidade. Refletir sobre a construção da paisagem urbana do Rio de Janeiro é pensar sobre hierarquias sociais, exclusões, gentrificação. As inúmeras intervenções realizadas na cidade ao longo dos séculos XX e XXI nos obrigam a problematizar a noção de especulação imobiliária. Constituidora de projetos concorrentes de cidade, seus agentes precisam ser nomeados, juntamente com os programas, projetos, normas e leis que thes garantem a atuação dentro das regras ou em suas brechas, para ser compreendida como um modo de operar na cidade, autorizado e interessado. Isso nos permitirá compreender melhor as relações entre patrimonialização e mercantilização da cidade e problematizar as diferentes funções do patrimônio, que se apresentam nessa arena nem sempre conectadas com a sua função social.

Ainda se verifica a predominância da perspectiva estética paisagística na proteção de paisagens e jardins históricos no Brasil, com pouco investimento na produção de conhecimento acerca da massa vegetal que os compõe e dos seus modos de ser, viver, se reproduzir e se transformar, em diálogo com a vivência de seus usuários. Isso nos fala sobre os diferentes modos como as paisagens podem ser apropriadas e, portanto, dos sentidos e funções, além da sua forma: conectar corpo e alma, para superar a nefasta divisão entre patrimônio material e imaterial e ampliar as imagens da cidade, múltipla, contraditória, complexa.

É assim o Aterro, metonímia da cidade, fronteira física e simbólica de formas, sentidos e funções, patrimônio que resiste, esbarra e avança sobre o mar e a paisagem urbana do Rio. 


\section{REFERÊNCIAS}

ABREU, Maurício de. Evolução urbana do Rio de Janeiro. Rio de Janeiro: Iplan-Rio/ Zahar, 1988.

AGUIAR, Leila Bianchi. Turismo e preservação do patrimônio cultural no Brasil. Tese (Doutorado em História) - Programa de Pós-graduação em História, Universidade Federal Fluminense, Niterói 2006.

ARNAUT, Jurema Kopke Eis. Morro da Conceição, Rio: uma proposta de preservação sem tombamento. Revista do Patrimônio Histórico e Artístico Nacional, Rio de Janeiro, n. 19, p. 97-111, 1984 .

ATA da $23^{a}$ reunião do Conselho Consultivo do Patrimônio Cultural. Rio de Janeiro, 10 ago. 2000. Arquivo Central do Iphan, Processo n. 748-T-64 - Parque do Flamengo.

ATA da $44^{\mathrm{a}}$ reunião do Conselho Consultivo do Patrimônio Histórico e Artístico Nacional. Rio de Janeiro, 20 abr. 1965. Arquivo Central do Iphan, Processo n. 748-T-64 - Parque do Flamengo.

ATA da 50 $0^{\mathrm{a}}$ reunião do Conselho Consultivo do Patrimônio Cultural. Rio de Janeiro, 9 nov. 2006. Arquivo Central do Iphan, Processo n. 748-T-64 - Parque do Flamengo.

BURLE MARX, Roberto. A função do jardim. In: TABACOW, José (Org). Roberto Burle Marx: arte e paisagem (conferências escolhidas). 2. ed. São Paulo: Studio Nobel, 2004, p. 206-213.

CAMPOS, Pedro Henrique Pedreira. Estranhas catedrais: as empreiteiras e a ditadura civilmilitar, 1964-1988. Rio de Janeiro: EDUFF, Faperj, 2014.

CARDOSO, Flora. Rio de Janeiro patrimônio mundial: a "invisível" paisagem entre a montanha e o mar. Dissertação (Mestrado em Arquitetura e Urbanismo) - Universidade Federal de Pernambuco, Recife, 2016.

CAVALCANTI, Lauro. As preocupações do belo. Rio de Janeiro: Taurus, 1995.

Quando o Brasil era moderno: Guia de Arquitetura (1928-1960). Rio de Janeiro: Aeroplano, 2001. 
CHUVA, Márcia Regina Romeiro. Fundando a nação: a representação de um Brasil barroco, moderno e civilizado. Topoi, Rio de Janeiro, v. 4, n. 7, p. 313-333, jul.-dez. 2003.

Os arquitetos da memória: sociogênese das práticas de preservação do patrimônio cultural no Brasil. Rio de Janeiro: Ed.UFRJ, 2009.

Por uma história da noção de patrimônio cultural no Brasil. Revista do Patrimônio Histórico e Artístico Nacional, Rio de Janeiro, n. 34, p. 147-165, 2012.

Patrimônio cultural no Brasil: proteção, salvaguarda e tutela. In: SOUZA LIMA, Antonio Carlos de (Org.). Tutela: formação do Estado e tradições de gestão no Brasil. Rio de Janeiro: e-papers, 2014.

COMITÊ TÉCNICO DA CANDIDATURA DO RIO A PATRIMÔNIO MUNDIAL. Dossiê do Rio de Janeiro: paisagens cariocas entre o mar e a montanha. Rio de Janeiro: Iphan, 2011. Disponível em: <http://portal.iphan.gov.br/uploads/ckfinder/arquivos/Dossi\%C3\%AA\%20 portugu\%C3\%AAs\%2028\%20mar\%C3\%A7o\%202011\%20RJ.pdf>. Acesso em: 31 maio 2017.

COSTA, Lucio. Documentação necessária. Revista do Serviço do Patrimônio Histórico e Artístico Nacional, Rio de Janeiro, n. 1, p. 31-39, 1937.

Arquitetura dos jesuítas no Brasil. Revista do Serviço do Patrimônio Histórico e Artístico Nacional, Rio de Janeiro, n. 5, p. 9-103, 1941.

ELIAS, Norbert. O processo civilizador: uma história dos costumes. Rio de Janeiro: Jorge Zahar, 1989. [1939].

FARIA, Rodrigo de. Concepção e urbanização do Aterro do Flamengo: o debate técnico e intelectual entre a engenharia e a arquitetura moderna. Revista do Arquivo Geral da Cidade do Rio de Janeiro, Rio de Janeiro, n. 12, p. 101-121, 2017.

FERREIRA, Alda de Azevedo; ONO, Fernando. Passeio de Copacabana: o limite do discurso do jardim moderno de Roberto Burle Marx na paisagem cultural carioca. In: PESSOA, Ana; FASOLATO, Douglas (Org.). Jardins históricos: intervenção e valorização do patrimônio paisagístico. Rio de Janeiro: Fundação Casa de Rui Barbosa, 2016. Disponível em: <http:// www.casaruibarbosa.gov.br/arquivos/file/Seminarios/comunicacoes_JardinsHistoricos_2016. pdf>. Acesso em: 05 nov. 2017.

FONSECA, Maria Cecília Londres. O Patrimônio em processo - trajetória da política federal de preservação no Brasil. Rio de Janeiro: UFRJ/Iphan, 1997. 
Para além da pedra e cal: por uma concepção ampla de patrimônio cultural. In: ABREU, Regina; CHAGAS, Mário (Org.). Memória e patrimônio: ensaios contemporâneos. Rio de Janeiro: DP\&A, 2003.

G1 RIO DE JANEIRO. Nova Marina da Glória é inaugurada e devolve orla marítima ao Rio. Disponível em: <http://g1.globo.com/rio-de-janeiro/noticia/2016/04/nova-marina-da-gloria-einaugurada-e-devolve-orla-maritima-ao-rio.html>. Acesso em: 24 ago. 2017.

GILLOT, Gaelle. La nature urbaine patrimonialisée: usage et perception. Le cas de deux jardins marocains. In: GRAVARI-BARBAS, Maria. Habiter le patrimoine: Sens, vécu, imaginaire. Rennes: Presses Universitaires de Rennes (PUR), 2005, p.105-124.

GIRÃO, Cláudia. 2011a. " Parque do Flamengo, Rio de Janeiro, Brasil: o caso da marina - parte 1. "Arquitextos 12 (135.1). Disponível em: <http://www.vitruvius.com.br/revistas/read/ arquitextos/12.135/4014>. Acesso em: 13 nov. 2017).

GIRÃO, Cláudia. 2011b. " Parque do Flamengo, Rio de Janeiro, Brasil: o caso da marina - parte 2. "Arquitextos 12 (136.1). Disponível em: <http://www.vitruvius.com.br/revistas/read/ arquitextos/12.136/4048>. Acesso em 13 nov. 2017.

IAB - INSTITUTO DE ARQUITETOS DO BRASIL. Exposição homenageia os 50 anos do Aterro do Flamengo. 2015. Disponível em: <http://www.iab.org.br/noticias/exposicao-homenageiaos-50-anos-do-aterro-do-flamengo>. Acesso em: 24 ago. 2017.

IPHAN - Instituto do Patrimônio Histórico e Artístico Nacional. Bens tombados e processos de tombamento em andamento. Disponível em: <http://portal.iphan.gov.br/uploads/ckfinder/ arquivos/Lista\%20Bens\%20Tombados\%20Dez\%202015.pdf>. Acesso em: 24 ago. 2017.

LEAL, Cláudia Feierabend Baeta (Org.). Consultores da Unesco no Brasil: Michel Parent. Rio de Janeiro: Iphan, 2009.

LEITCHIC, Berta. Entrevista concedida em 19 dez. 2000. In: FREIRE, Américo; OLIVEIRA, Lucia Lippi (Org.). Capítulos da memória do urbanismo carioca. Rio de Janeiro: Folha Seca, 2002.

LIMA, João Franco. Ethel Bauzer Medeiros: trajetória no campo da recreação e do lazer. Dissertação (Mestrado em Lazer) - Universidade Federal de Minas Gerais, Belo Horizonte, 2009.

LISSOVSKY, Maurício; SÁ, Paulo Sérgio Moraes de. Colunas da educação: a construção do Ministério da Educação e Saúde. Rio de Janeiro: Iphan, 1996. 
MAGALHÃES, Cristiane. O desenho da história no traço da paisagem: patrimônio paisagístico e jardins históricos no Brasil - memória, inventário e salvaguarda. Tese (Doutorado em História) - Universidade Estadual de Campinas, Campinas, 2015.

MAHFUZ, Edson. The importance of being Reidy. Arquitextos, São Paulo: Vitruvius, ano 4, n. 040.03, set. 2003. Disponível em: <http://www.vitruvius.com.br/revistas/read/ arquitextos/04.040/652>. Acesso em: 24 ago. 2017.

MARINS, Paulo César Garcez. Novos patrimônios, um novo Brasil? Um balanço das políticas patrimoniais federais após a década de 1980. Estudos Históricos, Rio de Janeiro, v. 29, n. 57 , p. 9-28, jan.-abr. 2016.

MEDEIROS, Ethel Bauzer. Um milhão de metros quadrados para recreação pública. Arquitetura, Rio de Janeiro, n. 29, 1964.

MENESES, Ulpiano Toledo Bezerra de. O campo do patrimônio cultural: uma revisão de premissas. In: CONFERÊNCIA MAGNA NO $1^{\circ}$ FÓRUM NACIONAL DE PATRIMÔNIO CULTURAL. Ouro Preto, 2009.

MOTTA, Lia. Sítios urbanos e referência cultural: a situação exemplar da Maré. Tese (Doutorado em Urbanismo) - Universidade Federal do Rio de Janeiro, Rio de Janeiro, 2017.

MOTTA, Marly. Saudades da Guanabara. Rio de Janeiro: FGV, 2000.

Rio, cidade-capital. Rio de Janeiro: Zahar, 2004.

Carlos Lacerda: de demolidor de presidentes a construtor de estado. Nossa história, Rio de Janeiro, n. 19, p.72-75, maio 2005.

NASCIMENTO, Flávia Brito do. Blocos de memória: Habitação social, arquitetura moderna e patrimônio cultural. São Paulo: Edusp, Fapesp, 2016.

OLIVEIRA, Ana Rosa de. Bourlemarx ou Burle Marx? Arquitextos, São Paulo: Vitruvius, ano 2, número 013.01, jun. 2001. Disponível em: <http://www.vitruvius.com.br/revistas/read/ arquitextos/02.013/876>. Acesso em: 24 ago. 2017.

OlIVEIRA, Ana Rosa de; BARROSO, Cláudia Maria Girão. 2006. "SOS Parque do Flamengo. ” Minha Cidade 6 (070.01). Disponível em: <www.vitruvius.com.br/minhacidade/mc162/mc162. asp>. Acesso em: 24 ago. 2017.

PAIVA, Maria das Graças de Menezes. Sociologia do turismo. São Paulo: Papirus, 1995. 
PEIXOTO, Enaldo Cravo. Urbanização do Parque do Flamengo. Módulo, Rio de Janeiro, n. 37, ago. 1964.

PESSÔA, José (Org.). Lucio Costa: documentos de trabalho. Rio de Janeiro: Iphan, 1999.

PONTUAL, Virgínia; PICCOLO, Rosane. A demolição e a conservação das áreas centrais: planos, leis e transformações morfológicas no Recife, Brasil. DIEZ AÑOS DE CAMBIOS EM EL MUNDO, EM LA GEOGRAFÍA Y EM LAS CIENCIAS SOCIALES, 1999-2008, 2008, Universitat de Barcelona. Anais do X Colóquio Internacional de Geocrítica. Barcelona, 2008.

PROCESSO n. 748-T-64 - Parque do Flamengo. Arquivo Central do Iphan, Rio de Janeiro.

RIALLAND, Olivier. La patrimonialization des parcs et jardins remarquables: de conflits en consensus? Norois, Poitiers, t. 47, n. 185, p. 151-166, 2000.

RUBINO, Silvana. Enobrecimento urbano. In: FORTUNA, Carlos; PROENÇA, Rogério (Org.). Plural de cidade: novos léxicos urbanos. Coimbra: Almedina, CES, 2009.

SCIFONI, Simoni. A construção do patrimônio natural. Tese (Doutorado em Geografia) Universidade de São Paulo, São Paulo, 2006.

SMITH, Laurajane. Uses of Heritage. Londres, Nova York: Routledge, 2006.

TAVARES, Maria Goretti; CASTRO, Cleber Augusto Trindade. A patrimonialização como processo de produção social do espaço urbano. Sociedade e Território, Natal, v. 28, n. 2, p. 117-135, jun.-dez. 2016.

TEIXEIRA DA SILVA, Francisco Carlos. A modernização autoritária: do Golpe Militar à Redemocratização 1964/1984. In: LINHARES, Maria Yedda (Org.). História geral do Brasil. Rio de Janeiro: Campus, 2000.

THOMPSON, Analucia. Campo cultural e contexto histórico: nomes do Iphan. In: MOTTA, Lia (Org.). Um panorama do campo da preservação do patrimônio cultural. Rio de Janeiro: Iphan/ DAF, 2015.

Artigo apresentado em 05/06/2017. Aprovado em 14/08/2017.

All the contents of this journal, except where otherwise noted, is licensed under a Creative Commons Attribution License (cc) BY 